\title{
'There you are like a bird in a cage!' Indian garment workers critiquing Fordism and CSR
}

\section{Draft version - not for quotation}

\section{Geert De Neve}

\section{Introduction: Making T-shirts, making persons}

For quite some time now anthropologists have engaged with the impacts, meanings, and experiences of the restructuring of global production systems on workers involved in industrial employment across the globe. The shift in global production regimes that has attracted perhaps most attention - of not just anthropologists but of all social scientists - was the gradual transformation from the 1960s onwards of Fordist and Taylorist production regimes into networks of flexible production, and the concomitant shift of much production from Europe and North America to those parts of the world where commodities and services could be produced more costefficiently, more speedily and indeed more flexibly (Harvey 1989).

The rise of flexible production systems and the outsourcing of production to those parts of the world where labour is cheap and abundantly available, provided anthropologist with a new laboratory to research labour under industrial capitalism in new social and cultural contexts. It did not take long before ethnographers zoomed in on questions of governmentality; questions of control and exploitation, especially of women employed because of their assumed qualities of 'nimble fingers', low skill and cheap labour (Freeman 2002); questions of resistance and of the ways people opposed new production regimes (Ong 1987); and questions of the nature of class consciousness and class solidarity in contexts where labour is dispersed in workshops of different size and shape. On balance, flexible specialisation, drawing on flexible regimes of production and labour inputs, has not been portrayed very favourably in ethnographic accounts. Flexible production is commonly presented as containing extreme forms of exploitation because its logic is based on extracting maximum value for minimum reward. Piece-rates, low wages, long and irregular working hours, poor 
working conditions, coercive forms of control and highly gendered forms of subjugation have all been extensively discussed as key ingredients of this particular mode of production in export-orientated industries across the globe.

In this paper, I seek to approach flexible production, the concept of flexibility, and the flexible worker from three different perspectives. First, I seek to move away from the teleology present in much of the literature, in which a unilineal development from Fordism to post-Fordism or flexible specialisation is assumed to be a one-way and irreversible process, in which the latter replaces the former. In this paper I present material, gathered during a year of fieldwork between July 2008 and July 2009, on the Tiruppur garment industry, located in the state of Tamil Nadu in South India.

Tiruppur is one of the largest knitwear garment manufacturing and exporting clusters in South Asia. It has boomed almost without interruption since the early 1970s when manufacturers began to export to Europe and today it is a leading centre of garment exports for the world market. The Tiruppur industrial cluster constitutes one of India's important foreign exchange earners, with a total export value of around Rs 11,000 crore or $\$ 2$ billion in 2007. Estimates suggest that there are about 10,000 production units in Tiruppur, employing more than 400,000 workers, but real numbers may well be higher than this ${ }^{1}$. While this cluster, like many other garment export centres, has commonly been described as a site of flexible accumulation, Fordist and flexible production systems in fact exist side by side. Large export companies employing hundreds and even thousands of workers have come up alongside hundreds of small workshops employing anything from a handful to 100 workers. The Tiruppur cluster therefore provides an excellent site to study the articulation of different production system within a single industry.

Secondly, I seek to critique what I call a romantisation of the Fordist mode of production. This romantisation has been constructed on the one hand out of a particularly negative portrayal of its alter-ego, the flexible mode of production; and on the other hand out of a selective forgetting of the less attractive features of Fordist

\footnotetext{
${ }^{1}$ Much of the labour force consists of commuters from the region, long-distance migrants (mainly recruited from the southern districts of Tamil Nadu), and increasingly also migrant workers coming from as far as Manipur and Nagaland in North-East India (De Neve 2003).
} 
production regimes. The latter include the often far-reaching processes of de-skilling, increased alienation from the end product, a lack of control over one's own time and pace of work, an absence of any form of flexibility, and finally extraordinarily monotonous and repetitive routines of work on the assembly line (Carrier 1992).

Thirdly, analyses of Fordist and flexible labour regimes have inadequately addressed the issue of flexibility itself: the ways in which it is generated, its meanings for workers in different cultural settings and the sorts of workers and persons such regimes ultimately produce. Here, I will unpack not only what flexibility means to workers employed under flexible production regimes, but also what workers themselves prefer and seek to achieve through flexible work, and indeed how they are implicated in the production of flexibility itself. Flexible workers have agency, and it is some of that agency that I seek to uncover in this paper and to place more centrestage.

In the Tiruppur garment industry, we find a wide range of production and labour regimes, with major differences between dyeing and processing houses, knitting units and garment manufacturing companies. Here I focus on the export garment manufacturing units that are also known as CMT or cutting/manufacturing/trimming units. Within these we find again a range of production regimes, but organisationally they can be divided into two broad categories: the large export company which employs hundreds of garment workers on what resembles the Fordist or Taylorist assembly line, and the smaller flexible workshop which employs a variable number of tailors producing garments in a flexible manner. The large factories use what is locally referred to as 'the line system' and tend to produce bulk orders for large buyers. Under the line system, the production of a garment is broken down into a series of different operations and the garment passes along a single line of tailors each of whom is responsible for one particular stitch. Tailors spend their entire day repeating the same stitch to the same part of the garment. Such factories work to fixed shift times and under the watchful eye of a line supervisor.

Alongside these large export companies, we find hundreds of smaller workshops where a variable number of workers are employed through labour contractors to produce smaller batches of garments in a flexible manner. Here, the workforce is 
divided into a line of singer tailors and a line of powertable tailors (doing flatlock and overlock stitches), and the garment is produced by a smaller number of workers each of whom perform different stitches on each garment. In these smaller production units workers are flexibly employed in terms of working hours, the number of operations they are required to perform on each garment and the constantly changing styles and fashions they are producing. In sum, Taylorist regimes by and large overlap with the larger manufacturing companies, while the flexible mode of production is typically found in the smaller workshops, who may be export firms or subcontractors. Medium-sized firms, typically employing between 50 and 200 workers tend to use a combination of production methods, but often veer towards the more flexible labour regimes of the smaller workshops.

But production and labour deployment regimes are not only shaped by type of company, size of orders or required speed of production, they are also, and increasingly so, shaped by the newly imposed labour codes and labour standards through which western buyers seek to improve the conditions of employment in their production networks. While the Corporate Social Responsibility (CSR) concerns of western companies cannot be reduced to a set of codes and standards, in sectors such as food and garment production such labour codes nevertheless form the primary tool through which buying companies and chain stores seek to influence the social and environmental conditions of employment in their sourcing networks (Nadvi and Wältring 2004: 71-73). These ethical or labour codes and standards - the central tools of western CSR interventions - have begun to make their inroads into Tiruppur as well.

A burgeoning literature has emerged that concerns itself with the definition, classification and implementation of such codes and standards (Nadvi and Wältring 2004; Nadvi 2004, 2008), and their relative success in improving conditions of work for male and female workers (Barrientos, Dolan and Tallontire 2003; Barrientos and Smith 2007). Yet few scholars have questioned what such codes and standards 'do' to the companies and workers on whom they are imposed, and what sorts of labour regimes, industrial disciplines and 'values', 'workers' and 'persons' they seek to produce. Here, I am interested in the ways in which western corporate standards seek to create a particular type of garment factory and a particular type of garment worker. 
Let me make two observations here. First of all, there seems to be a close 'fit' between corporate labour codes and standards and Fordist production regimes. Both seek to establish a similar work regime (albeit for different reasons) in which a regularly employed labour force produces a mass product according to well specified tasks, fixed time schedules and close supervision. Both discourage more flexible irregular work arrangements. The Fordist company's rationale behind this is to optimise production speed and output, and thus to maximise profit, while buyers seek to impose labour standards that lead to regular employment patterns and that avoid the sorts of exploitation that gives them bad publicity. As such, labour codes and standards map well onto a Fordist company, and it is no coincidence, therefore, that also in Tiruppur we find labour codes and standard applied almost exclusively in the largest export companies, where the requirements of CSR policies have much affinity with the requirements of the Fordist assembly line. Secondly, Western corporate codes and labour standards not only breathe nostalgia for a Fordist mode of production, in which labour is systematically deployed according to set rules, agreements and schedules, they in fact help to reproduce and reinforce such Fordistlike production regimes. Indeed, corporate labour codes and standards are playing an increasingly central role in the fixing and rigidifying of labour processes within large export companies by imposing 8-hour shifts, regulating overtime and standardizing contracts. Through such measures they seek to produce rigid labour regimes and counteract the flexible deployment of labour found in the smaller, flexible firm. In Tiruppur, the leading manufacturers and exporters embrace such codes and standards, and adjust their production systems in line with buyers' requirements, in their search for access to global markets (De Neve 2009).

Some authors have begun to comment on the transformative and authoritative nature of such corporate interventions. They have asked what such interventions mean in terms of the new modes of "governmentality" they engender (Dolan 2007: 251) and the sort of fit (or lack thereof) between the values embodied in ethical standards and the values pursued by workers themselves (Blowfield and Dolan 2008: 10; Nadvi 2008; Lund-Thomsen and Nadvi 2009). In particular, recent work on CSR has recognised the need for more detailed studies of the impacts of CSR initiatives on workers and communities (Prieto-Carrón et al 2006). 
In what follow I explore what workers themselves make of the 'benefits' conferred by these standards and explore how and why some garment workers actively seek to avoid employment in companies where Fordist regimes prevail and where CSR policies are implemented. Such avoidances, I argue, constitute a direct critique of Fordist production modes and of CSR interventions on the shopfloor in that they reflect workers' attempts to evade regimes and regulations that curb their freedom, autonomy and dignity. Workers' preference for work in non-compliant, flexible companies reveals how they wish to avoid Fordist regimes and corporate regulatory interventions that rob them of control over their own labour and their everyday work routines. Their choices about where, when and how to work reflect attempts to regain control over their own working lives at a time that they are being affected by new forms of time disciplining and spatial control that seek to reduce their freedom at work.

\section{Fordist/Compliant versus Flexible/Non-compliant Firms: Producing 'company employees' and 'contract labourers'}

But let me now turn to Tiruppur itself. As I said above, today, the distinction between the larger Fordist companies and the smaller flexible units largely overlaps with the distinction between complaint and non-compliant firm. The larger companies are the ones who have been able to bring their management and production systems in line with the labour requirements of buyers. These requirements take the form of company codes of conduct, first introduced around 2000, which are made up of a fairly fixed list of regulations, set by the buying company, and which their supply firms are asked to comply with (see Figure 1). They are private company initiatives that allow buyers to select supply firms on the basis of their relative compliance with a series of regulations ${ }^{2}$.

Figure 1. Generic ethical code of conduct

1. Compliance with local labour laws and workplace regulations

\footnotetext{
${ }^{2}$ Tallontire uses the term 'private standard initiatives' to refer to 'all standards set outside the realms of public sector', and distinguishes between private company standards (set and monitored by a single firm) and private collective standards (that have their roots in collective, often stake-holder or industry based initiatives) (2007: 777).
} 
2. Prohibition of child labour.

3. Regulation of contract labour.

4. Non-discrimination.

5. Prohibition of forced labour.

6. Freedom of association and the right to collective bargaining.

7. Humane treatment.

8. Minimum wages, living wage and other benefits

9. Regulation of working hours

10. Working conditions (health and safety)

In addition to company codes of conduct, several international voluntary labour standards have made their inroads into Tiruppur too, the most prevalent of which are the Social Accountability 8000 standard (SA 8000) and the Worldwide Responsible Apparel Production Certification (WRAP). These are generic standards that seek to harmonise social minimum standards across industries. They incorporate the core ILO labour standards, refer to national legislation and aim to streamline independent company codes (Nadvi and Wältring 2004: 81-84) ${ }^{3}$. Tiruppur exporters can obtain certification for their garment factories by putting the required social management systems in place, having their units audited by an independent auditing company and so receive standard accreditation which then allows them to sell to buyers (De Neve 2009).

However, only the largest export firms, who can rely on regular orders from major buyers and who produce bulk orders using the 'line system', have been able to comply with codes and standards. They are the companies who are able to make the necessary investments in factory buildings, canteens, workers' hostels, toilet facilities, and so on, and who can bring their labour management systems in line with those of the standards. These include adherence to 8-hour shifts, regulation of overtime and the provision of regular contracts with social provisions made available for the entire workforce. In a Fordist garment company workers are recruited as 'company

\footnotetext{
${ }^{3}$ SA 8000 was developed by Social Accountability International (SAI) and is primarily used by Europe-based chain stores and buyers. WRAP is an independent non-profit organisation based in the US, whose certification is mainly used by US-based companies.
} 
employees' on regular contracts. The Fordist model requires a permanent and stable labour force and this requirement is compatible with the type of labour regime corporate codes and standards seek to produce. As they produce for major western buyers and brand names (such as GAP, Primark, Marks \& Spencer, Carrefour, Decathlon), they are also most likely to be subjected to repeated and intrusive inspections and social audits on the shop floor, conducted by both third party auditors and buyers' representatives. The majority of manufacturers, however, and especially the smaller subcontractors and jobworkers, work with unpredictable and fluctuating orders, flexible schedules and a variable labour force. Flexibility being their comparative advantage within the industry, flexible companies thrive on a workforce whose numbers it can increase or decrease as and when needed. Such smaller companies find it difficult to comply with the demands of westerns buyers and thus continue to produce garments under non-compliant and flexible regimes. The result is a two-tier system, in which two types of company exist side by side in Tiruppur: the Fordist/compliant and the Flexible/non-compliant company.

What does it mean for a worker to be employed in a compliant firm? Below I will discuss how workers perceive work in different firms but here I mention some factual characteristics. First, workers are employed as a 'company employee', which means that they are on a permanent payroll, and benefit from a social security scheme (ESI, or Employees' State Insurance), a pension fund (PF, or Provident Fund) and an annual bonus paid at the time of Diwali. Workers are paid a fixed wage per shift and receive a monthly salary. In theory, employees cover an 8-hour shift, typically from 8.305.30, with a one-hour lunch break and two tea breaks announced by the ringing of a bell. The physical conditions of work in such companies tend to vary - by any global standard - from good to excellent. Most factories are spacious, airy, clean and welllit, with health and safety provisions made available throughout the company (such as fire exits, First Aid Kit, etc

What then does a non-compliant company look like? Non-compliant companies can take different forms. Most of them, however, are smaller units, often acting as indirect exporters or subcontractors and jobworkers. They employ anything from a handful to a few hundred workers. In these units, only a few employees (supervisors, managers and some checkers) are on the permanent payroll, while the tailors, cutting 
masters and ironing masters tend to be employed through labour contractors. Labour contractors have become a central figure on the shop floor. The contractor agrees with the management to take an order, of e.g. 10,000 T-shirts, for an agreed payment, which he then has to produce to a specified deadline and quality standard. The responsibility of the contractor consists first and foremost of recruiting workers. As a consequence, the primary task of a labour contractor is to mobilize an adequate labour force and to get them to work at such a speed and to such standards that the contract is completed on time and to the required quality specifications. In any one garment unit, four or five contractors may be recruited at the same time: one contractor will recruit power table tailors, another will recruit a team of singer tailors, and another one a group of cutting masters to cut the cloth, etc. Under this system most workers are employed by contractors and not by the company itself.

Workers recruited through contractors only have job security for as long as the contract lasts, which can be anything from a few days to a couple of months, but more typically two to three weeks. Once a contract has been completed, a tailor can follow his contractor to another company or join another contractor altogether. But permanent employment is never guaranteed. Under this system, workers are paid either piece rates or shift rates by the contractor, depending on a series of factors, including skill, experience, quality and design of garment, type of machine, and so on. On the whole, however, piece-rates have become increasingly common over the last 5 to 10 years. While much more can be said about the role of the contractor, what I want to emphasise for now is the extent to which the use of contract labour, recruited and managed through labour contractors, has become a common form of labour recruitment within a large section of the industry. As casually employed contract labourers none of the workers in such firms benefit from social insurance schemes, and all receive a weekly pay on Saturday evenings, the level of which varies according to the number of shifts worked or the number of pieces completed over the last 7 days. But, not all is bad here: as contract labourers, workers have the potential of earning considerably more than they make in large, compliant firms, and, as we shall see, they benefit from valuable flexibilities and freedoms that make their working lives more manageable.

\section{Why one-size-doesn't-fit-all: what garment work means for labourers}


Seen from a worker's perspective, Tiruppur's industrial landscape effectively offers two options: employment in a large, compliant export house as a 'company employee' or work for a smaller and flexible, non-compliant firm as a casual 'contract labourer'. What do garment workers in Tiruppur prefer? What do they get out of these different modes of employment? What do they value in their work and working lives? And how do their values and priorities 'fit' with those aspects of work that labour standards seek to promote? Let me introduce some people and some shop floor relationships.

'There you are like a bird in a cage!': reflections on freedom, flexibility and dignity

I first met Mohan when he worked as a singer tailor in a small workshop opposite our house in the centre of Tiruppur. Mohan's father came to Tiruppur in 1997, after having made losses in a small tailoring shop in Madurai, about $200 \mathrm{~km}$ to the south of Tiruppur, and came with his wife, 7 sons and 1 daughter, aged between 19 and 3 years of age. Having studied up to $5^{\text {th }}$ standard, Mohan learned singer tailoring in the tailor shop of his father's brother, and on moving to Tiruppur he started to work in an export company at the age of about 16. Aged 28 now, Mohan is unable to tell me how many export companies he has worked for in Tiruppur; '100, maybe 200, I don't keep track!' He works for different labour contractors and follows them to whatever company needs a team of singer tailors.

As is typical of tailors in the export industry, Mohan regularly moves from company to company and may work a few days in one unit, followed by a few months in another one. When I first met Mohan in December 2008, he worked in Modern Fashions, a small garment workshop that contains 8 singer machines and 8 powertable machines, and in which a maximum of 20 people are employed at any point in time. He had joined the team of the singer contractor who needed an extra tailor to finish off an order quickly. Mohan always works for piece rates and mentioned in one of our first conversations: 'I can earn well in this job, we earn a minimum of Rs 350-400 per day as singer tailors, but we can make even Rs 1000 per day. I earned Rs 3000 last week, and I can easily make Rs 12,000 per month, and sometimes even Rs 20,000 !' 
But Mohan doesn't always just work as a tailor; sometimes he is employed as a contractor and recruits tailors to work for him. In fact, just before Pongal, in January 2009, Mohan had left his contractor in Modern Fashions following an argument. He explained to me that disagreements typically arise about piece rates: 'We got low rates from the contractor. If I ask Rs 3.50 per piece and he is only willing to give me Rs 3, then we will simply walk out and tell him to get someone else. And we go and find work with another contractor. If time is good, we can stay with the same contractor and in the same company for years on end and do well...'. But time wasn't good for Mohan and he left and started as a contractor himself in a nearby unit. But by March, Mohan had shifted with his team back to Modern Fashions, where the company owner had asked him to 'take the singer contract'. Mohan worked as a contractor in Modern Fashions from March till the middle of August 2009. During this period, his team shrunk and expanded according to the amount of work available, but always included himself, his older brother, his sister, his cousin-brother and a good friend. When there was a lot of work, he called on another brother, his brotherin-law and some other friends as well.

Work in this company went fairly well, with a regular flow of orders and thus also of new contracts. But by July 2009 Mohan became dissatisfied with the low rates that he received from the owner and with the repeated delays in payments, which in turn made it hard for him to pay his tailors. On leaving the company in August, he explained: 'I left the contract, it wasn't worth the trouble, and I joined again as a tailor with another contractor in a new company.' When I visited him in this new unit in October 2009, Mohan was beaming again, telling me that the rates he was now receiving were excellent: 'I now get Rs 8.50 per piece and I can do 150 pieces per day!' I made a quick calculation and realised he now could make Rs 1275 per day. The following Saturday evening Mohan called to tell me proudly that he had made Rs 5600 that week: 'You see, there as a contractor I got Rs 3000 for 6 days of work, and here I have earned Rs 5600 as a tailor for only four and a half days of work!'

On several occasions, when Mohan and his brother Palaniveel were talking about the many 'risks' of their job, I asked them why they didn't join a large export house (or a compliant company), where they would enjoy job security, regular wages, ESI, PF 
and an annual bonus. But they dismissed this option out of hand: 'Here, there is no tension and no headache; in large companies there is lots of stress. Also, here there is no timing, we can go and come as we like; we don't have to follow fixed shifts. There we get no madipu (respect, recognition) for what we do. The owners and managers there do not give respect to what we do. And anyway, there the salary is inadequate; there even singer tailors are paid shift rates!' But what about PF and ESI, I asked. 'PF is of no use to us, only $20 \%$ of the companies actually pay it when we leave, and ESI contributions reduce the salary even further!'

On another occasion I was talking in Modern Fashions to Rajkumar (26), a powertable tailor, who is paid shift rates, and I asked him the same questions. He replied: 'There [in large export houses] you can't talk and be free, while here - as long as we make the garment without mistakes - we can chat and be jolly! In large companies there are huge numbers of people working and I was scared of the crowds too.' In Modern Fashions, the workers all know each other well; they spend time together playing cards in evenings, visit each other's houses and go to the cinema on days without work.

When asked why they are working for a contractor in a small unit rather than as a regular company employee, the standard response is always 'we just can't work there!' Inbaraj, Mohan's cousin-brother who is only 23 but has several years of experience as a singer tailor in Tiruppur, clarified what he meant with 'we just can't work there': 'In those companies, there are too many rules and regulations! We have to be in our seat by $8.30 \mathrm{am}$, we can only leave at $10.30 \mathrm{am}$ for the tea break and then for lunch and we can only go home at $8.30 \mathrm{pm}$. If we are not feeling well or there is a family function, we cannot get any leave. We can't work there. Those companies are like a jail; you can't escape! You are like a bird in a cage! Here we are free and we can go and come as we like; you see if I suddenly have some urgent work, I can tell the contractor and go; we haven't got those problems here!'

While a typical working day in the small subcontracting units also runs from 8.30am till $8.30 \mathrm{pm}$, the tailors do enjoy a considerable amount of freedom. Often they do not arrive until closer to $9 \mathrm{am}$, and those paid piece rates even till 10 or 11am. One day, I half-offended Senthil, the powertable contractor, by asking when he walked into the 
company at 9.30am: 'why do you guys always start so late in the morning?' He retorted with a question: 'When do office people start work?' I said: 'At 9am or 9.30am.' 'Well, that's also how I work', he replied, 'I get up at 8am, take a bath, have breakfast, take my daughter to school on the bike, and then I come to the company. I work like office people do!' Senthil likened himself to an office worker, not in terms of the actual work he does, but in terms of the control he has over his working hours and his work routines, a control which he highly values as a matter of both freedom and dignity at work. Tailors also emphasise the importance of being able to be 'their own boss', which is usually expressed through phrases such as 'nobody asks us when we come and go', 'we can be free and jolly here', and 'here we have no tension, no supervisor or owner chasing us up'.

When employed by labour contractors workers do indeed enjoy a considerable amount of flexibility at work, not in the least because the relationships between tailors and contractors are close and cordial. Contractors and their team members are often related as kin, as migrants or commuters coming from the same village, as members of a same caste, as friends, or as a combination of any of the above. Mohan's team of singer tailors, for example includes one of his brothers, his sister, his cousin, and a friend from Madurai. If he needs more tailors, he calls on his sister's husband, other bothers and other local friends. Flexibility always works both ways. If a tailor needs a two hour lunch break in the middle of the day to take care of some 'personal work', he can easily get this time off too. And even the women working as checking ladies who are paid by the shift can easily get half a shift off whenever they need it. In return, team members have to be flexible as well: if an urgent order has to be sent off, they will stay on till midnight and work a double shift, and it is not uncommon for them to work a vidi night (or dawn night) if a deadline is just around the corner, which means work till the early morning hours, usually about $5 \mathrm{am}$. If they do not manage to finish the order by Saturday evening, the tailors come back on Sunday and work a 7day week. Tailors have internalised the importance of keeping to deadlines and know that if they fail to meet a shipping date the order might be rejected and salary payments never made.

Male tailors thus value the freedoms they enjoy at work and they see the workshop as a site that blurs kinship, friendships and work relationships and where the routines of 
work can be brought in line with the rhythms of domestic life. Workers enjoy the freedom to have their earphones plugged in to listen to music while at work, to talk on the phone to family and friends as they please, and walk out for a break whenever they feel like having a cigarette or just stretching their legs. Work in large export houses and compliant firms, by contrast, is dictated by fixed shifts, a lack of spatial mobility and constant supervision on the line.

\section{'Even if a tsunami comes...': what women value at work}

The freedoms and flexibilities which male workers so value are equally - and possibly even more - significant for women workers who dwell at length on the differences in temporal routines and supervisory regimes between large export houses and smaller workshops.

One afternoon, I ended up talking to a group of 8 women, who were checking and trimming export garments. All of them were standing around two large tables at the centre of a small room, attached to the rear of the owner's house. The room had no windows but a roof that let in some day light through four glass roof tiles. Above the checking tables hung a fan and three tube lights that were switched on in the evenings when it got darker in the room. This is a fairly typical checking centre, set up by a man who himself is busy taking garments back and forth between his place and the large export companies that outsource this sort of work. Trimming and checking of finished garments is routinely outsourced by larger export houses - especially when deadlines loom near - to small specialist checking centres. The room looked rather dark and crammed to me, with hardly any space to stand between the checking tables and the walls. I therefore asked the women why they hadn't gone for a larger company with better facilities and with a range of benefits such as ESI, PF, etc. Some of them said that they had worked in such companies before, but they were all in agreement that Fordist regimes don't work for them: the strict shift timings and the restrictions on movements in such companies does not allow them to fit in paid work with their domestic and family responsibilities. One of these responsibilities includes the collection of water from nearby public taps. Municipality water is released once or twice a week, but never at predictable times. When the water arrives, it runs only for a few hours and at that time women have to be able to run home and fill their 
buckets. 'Here', the women explained, 'we can go home to fill our buckets whenever the water is released and then come back to work, but in those companies that would never be allowed. Whether water comes or even a tsunami comes, we have to stick to our checking tables!' Can you always get leave here, I asked? 'Yes, he's our chetan (older brother, in Malayalam), isn't he, so he is really good for us! We can go and come as we like!'

All eight women live just minutes away from the checking centre and they are allowed by the owner to run home whenever the word spreads that water has been released. Similarly, in the mornings they can arrive at 9am or even later, after having sent their children to school and done the day's cooking. At the 6pm tea break, they all go home again to let their children in from school and to feed them a snack. By $6.30 \mathrm{pm}$ they are back at work - with or without children - and continue till $8.30 \mathrm{pm}$, when they return home to prepare the evening meal. Unlike men, few women garment workers have access to the modes of transport (such as cycles and bikes) or avail of the spare time necessary to cross the city in search of work in a company several miles away. Women prefer work that is close to home so that they can run back and forth throughout the day to take care of whatever work needs attention at home.

But they also mentioned the strict supervision and rigid discipline that marks the work routines in big export companies. Gayathri, who used to work in a large export house, explained it this way: 'There, we can't even talk to the person next to us. The supervisor will immediately shout at us and say that our work will be affected. We are not even allowed to look left or right. We have to work like this only!' and she illustrates how she was physically expected to work, by bowing her head deep over the table and looking straight down onto the garments. All women burst out in laughter but confirmed that this is indeed how they are expected to stand at their tables and work in such companies. They went on to explain how in this checking centre they can talk and chat and discuss the loves and losses in their lives, sharing experiences among a small group of known people (see also Salzinger 2003). It is the shopfloor as a site for social interaction that women value. The owner stood next to us, nodding away smilingly. 
Hence, for women, freedom and flexibility are essential to make their participation in paid employment possible, and their everyday work routines more pleasurable and satisfying. Yet for them flexibility is both about personal autonomy (such as the ability to turn the workplace in a sociable space, as we showed was important to men) and about spatial and time flexibilities that allow them to combine their domestic work with company work. All of this goes some way to explain why small local units, like this checking centre, are often preferred by women over large export houses. But why would the owner of such a unit allow his women workers such flexibility and relaxed work discipline? The answer is straightforward. He has to be flexible to be able to gain their loyalty. In a context where he himself is unable to provide women with regular work, he might have to send them home without work for days at end, while at other times he will need them urgently, or may even have to ask them to work overtime. When suddenly 5,000 T-shirts arrive for checking, he will be rushing to their houses to call them to the centre, and he will be insisting that they work till the order is finished. It is precisely because he needs a flexible and loyal labour force that he is willing to be flexible himself. In Tiruppur's numerous small workshops, flexibility works both ways: it is produced by the employers as much as it is engendered by the workers themselves.

Women with young children, and especially migrant women with children, find it particularly hard to take on a garment job that requires them to stay inside a company for 8 or 10 hours at a stretch. But even for women without children there are limits to what sort of garment work they can do, and why the Fordist, compliant company might not even be an option for them. Women's choices are heavily shaped by ideas of what is appropriate work and curtailed by male control. Selvi, Mohan's sister, for example, got married several years ago and remained childless after the stillbirth of her twin babies. I met her first in March 2009, when she was working as a singer tailor in Mohan's team. There she enjoyed a relaxed routine. She never turned up for work before 10am. She told me that she finishes all her domestic work first and then walks to the company. Similarly, in the evenings, she leaves home whenever the domestic calls. Her husband is also a singer tailor but he moves between different companies. I asked Selvi whether it was her own choice to work and she said it was: 'At home, they said I shouldn't work, there is no need for it, but I like to work, I get bored sitting at home, so I decided to come anyway, it's my choice. And it's with 
family, so they let me.' Yet, when I meet Selvi again a few months later, this time in Mohan's house, she is no longer working. As I ask her why she has stopped, she replies in a rather sad way: 'Since Mohan stopped taking contracts, I can't work anymore, they are not letting me go elsewhere'.

I realised that what Selvi initially presented as her own choice was in fact much more shaped by the control and decisions of her male relatives: as long as Selvi could stitch alongside Mohan, she was allowed to work, but once Mohan stopped working as a contractor, she was not allowed to join another team. At one level, the contract-based system did open up an opportunity for Selvi to work. She would never have been allowed to work in a larger export house for 12 hour shifts. At another level, however, her choice is clearly curtailed by male authority - both that of her husband and her brothers. Mohan said that 'there is no need' for his sister to work, yet he did allow her to join him as part of his own team, where she was said to be 'just helping out'. While many husbands may not allow their wife to work in large companies, women's work alongside male kin is more widely accepted as it can easily be constructed as merely 'helping out the family' rather than 'working for money'. Smaller workplaces and contract-based recruitment systems offer women certain opportunities to work, even though their freedoms may be heavily controlled by male kin, be they husbands, brothers or sons.

So, who then is working in the Fordist, compliant firms? After all, those companies to do have a work force too. To understand who chooses to work as a regular company employee, and why, we need to look at workers' life course as well as their migration status. Let me say something about both. As women progress from being young unmarried women, to married wives, to mothers of young children and finally mothers of working adults, their own options and priorities shift considerably over time. As young women, they may opt to work in large export concerns, as checkers, helpers and even tailors, and live in a hostel, or accommodation provided by the company. At this stage they can often be released from domestic work in their parents' house but their money earning capacity may be highly valued - especially in the run up to their marriage. Take the case of Jansi, a 24 year old unmarried woman from Dindigul, a neighbouring district to Tiruppur. I talked to Jansi alongside a female research assistant in Millenium Apparels, a large compliant export house. 
Having failed her $10^{\text {th }}$ class exams, Jansi took a one year tailoring course in Dindigul, where her parents are cultivating a few acres of land. She is the only daughter to her parents and claims to know nothing about agriculture. Her story of how she came to Tiruppur was revealing to us. One day while she was just sitting at home, a van from Global Textiles, a large accredited Tiruppur export company, came along, distributing leaflets that read 'young workers wanted'. They showed video clippings about the Tiruppur company, and invited young women and their parents to come to Tiruppur and see the factory for themselves. They promised good food, a secure working environment, safe accommodation and money. Jansi managed to convince her parents to let her go to Tiruppur, and got a job in Global Textiles where she became a powertable tailor within two months of arriving. She got regular work and earned about Rs 3500 per month, from which a fixed sum was deducted for food and hostel fees.

While Jansi initially enjoyed working there, over time the flow of work became increasingly irregular and so did her pay. Periods marked by low orders and a lack of work on the shop floor were followed by bouts of very intense activity during which she was forced not only to work successive night shifts but also consecutive weekends. In the end, she had had enough and along with 5 friends she left Global Textiles and joined Millenium Apparels. She says she now likes this company and is happy with the food and the accommodation. Her parents are currently looking for a husband for Jansi, and she is likely to get married within a year or two. Until then, however, she is adamant that she will be working in Tiruppur where she enjoys being independent and being able to earn for herself, and to have control over her own money. Like Jansi, Millenium Apparels employs many young, unmarried migrant women who tend to stay on for a few months or a few years before getting married and returning home. For them, the demands of Fordist mass production, which require uninterrupted work disciplines and a regularly employed labour force, do not interfere with the day-to-day pressures of family life. Living in company accommodation, these young women have few family demands made on them in Tiruppur and can adhere to the fixed and uninterrupted shift routines. The drudgery of some of the work is compensated by the novelty of working in the city, which includes the company of other young women, the opportunity to leave the firm for a 
film or some shopping on Sundays, and the freedom to spend at least some of their money as they please.

While these younger women are better placed to bear the demands of Fordist work routines, the case of Jansi and her 5 friends nevertheless exposes two telling features of the struggles of the larger export houses in attracting a regular labour force. One is that the Fordist regimes, which such companies seek to put in place and which are much advocated by CSR policies, are in fact almost impossible to sustain on the shopfloor. They directly clash with the demands of flexible production regimes and volatile consumer markets that generate volatile flows of orders and thus an unpredictable demand for labour on the shopfloor. Even in these large companies a great deal of flexibility is required, which undermines management's attempts to recruit and retain a stable labour force and to implement fixed and regular work schedules. Overtime work and underemployment are two sides of the same coin that limits companies' efforts at implementing uniform work routines on the shop floor. As a result even the largest firms are forced to retain a certain amount of flexibility. The second point that Jansi's shift from one company to another reveals is that there are clear limits to the extent to which even a compliant labour force - consisting of domestically unencumbered women workers - tolerates the excesses of labour demands. Whenever companies assign systematically too much or too little work - in the process taking women workers' flexibility for a ride - the latter do not hesitate to protest by simply moving on to the next company where they hope for a more sustainable combination of work loads and income levels. As a result, high levels of labour turnover are a persistent issue plaguing Fordist compliant firms, and many have few options other than to take recourse to contract labour.

But let us return to the life course of men and women working in this industry. Young women typically leave large garment companies, and often even the labour market altogether, once they get married - when husbands and in-laws may no longer allow them to work for money - or after the birth of a first child. With small children at home, women rarely work, unless they have other adults around to look after the children. Once the latter are at school, women re-enter garment work, but generally on quite different terms: usually in smaller units, in more flexible jobs, closer to home and often - because of the flexibility they require - in lower skilled and less well paid 
jobs. Even those women who were tailors before marriage, now end up working as helpers to tailors or as checkers, often alongside their husband or brother.

Home-based work is important too. Women with small children often opt for homebased work, such as garment trimming work or seconds sorting work, as this can be combined with childcare at home. Similarly, when they are older and less able to stand long hours at a checking table or sit 12 hours at a machine, women tend to return to either home-based trimming work or seconds sorting work in the small godowns scattered throughout the town. It is difficult to assess whether women opt for certain types of work out of choice or out of necessity, but what is apparent is that they assess different types of work and different work arrangements in terms of income, domestic constraints, personal abilities, flexibility and freedom. In as much as the industry requires certain forms of flexibility to be able to compete globally, so do male and female workers produce their own flexibility, or rather, opt for those work arrangements that fit with their gendered responsibilities and aspirations at different stages of their life cycle.

But a woman's life cycle and job trajectory are also affected by her migration status. Large numbers of men and women migrate to Tiruppur in search of work, and many of them arrive as nuclear households without extended kin support. This considerably curtails married women's ability to enter paid employment, and contrasts them sharply with the so-called 'locals', that is, those who were born and brought up in town, including those brought up in families who migrated to Tiruppur 15-20 years or more ago. In either case, men continue to be constructed as the main breadwinners, even if in reality they too suffer from irregular work and fluctuating incomes.

\section{Doing piece rates, performing masculinity, achieving mobility}

Let me return therefore to men and their relationship with garment work. While men value the flexibility and autonomy that they enjoy under a labour contractor, garment work also provides them with the opportunity to 'earn and spend', to 'outdo' the system, and to 'come up' in life. Garment work is central to the trajectory of becoming a man and performing masculinity on the shop floor, and the smaller, noncompliant companies provide a particularly productive stage for competitive 
performances and male aspirations. The workplace is important to these male trajectories given that men spend on average 12 hours, and sometimes even up to 20 hours, per day in the company, in the presence of male and female co-workers.

Work on the shop floor of smaller firms is to a considerable extent competitive. Even though tailors have to closely cooperate to complete a garment, they constantly compare the amount of work they do in a day and thus the earnings they take home. Singer tailors, cutting masters and ironing masters, who all work for piece-rates, endlessly go on about the number of pieces they are able to cut, iron or stitch in a day, and about the rates they earn per piece. Those on shift rates proudly tell how many shifts they have done in any week and thus how much they will make by the end of the week. Rajkumar, a powertable tailor in Modern Fashions, exclaimed: 'If we do 6 shifts we are okay, if we do 8 shifts we have a party, but sometimes we do even 10 or 11 shifts in a week!' Tailors pride themselves on their tailoring skills, the speed of their production, and their ability to work throughout the night, even two or three nights in a row if needed. Garment workers employed under labour contractors are thus deeply involved in what Burawoy has described as 'making out', the process through which piece-rate workers seek to make the most of the time and rates available. It is therefore not uncommon to find Mohan or his cousin, Inbaraj, at work till late at night, long after all others have gone home, in an attempt to finish a few more dozen of pieces.

Similar attempts at 'making out' can be found among the powertable tailors, and even among helpers and checkers, who are usually paid fixed shift rates. They will seek to do as many shifts per week as possible, and may complain to the contractor if he asks one tailor or helper to stay on for an extra half shift but not the others. Shift-rate paid powertable tailors have pragmatic reasons to work in flexible firms: they can earn more per shift (overlock tailors get Rs 120-130 in large firms and Rs 150 in smaller units; flatlock tailors get Rs 170-180 in large units and Rs 200 in smaller units), and they get the opportunity to do more shifts per week, as these units rarely implement maximum working hour regulations. In places such as Modern Fashions, workers can earn considerably more per week than in a big export house, even though they might not get regular work week after week. Moreover, recently even powertable tailors have begun to demand piece-based payment, something almost unheard of a few 
years back. Experienced powertable tailors are confident that they can earn more when paid by the piece, and that is why they now press their contractors for piece rates rather than shift rates.

I was able to observe this shift in the course of 2009 in Modern Fashions. At the beginning of the year all Senthil's power table tailors were paid on a shift-rate basis, but by May three tailors left the team to work for another contractor from whom they demanded piece rates. Two of the replacement tailors whom Senthil recruited for his team also asked for piece rates, and Senthil agreed to pay them in this way. He knows only too well that it is the only way in which one can keep hold of a good tailor. When I expressed my surprise at the fact that powertable tailors were now also pressing for piece-rate payment, Senthil confirmed that this is a fairly recent but rapidly spreading development, and reflected: 'It doesn't make much difference to me; they will work faster and make more money, that's all.' Under a piece-rate system Senthil can now get the order done with fewer tailors, but he has to make sure that the quality doesn't suffer. Senthil therefore explained that he wouldn't pay just any tailor piece-rates, but only 'good' tailors, that is, men with experience and with the ability to combine speed with quality stitching. Kathirveel, who was newly recruited on piece-rates, is one such tailor. He took great pride in the fact that he is paid piece-rates and told me on the first occasion we met that he can make Rs500 to 600 per day. On the days that I was assisting Kathirveel as a kaimadi (helper) at his machine, I struggled to keep up his pace of work and realised that he stitches considerably faster than the tailors on shift-rates whom I had assisted before. Throughout the day, Kathirveel reflected aloud on how much he had earned so far, and kept saying 'I've made Rs 200 this morning, I've made Rs 150 since lunch' and so on. Being a good and fast tailor is a source of pride that inspires admiration among fellow workers, who may seek to emulate the speed and quality of their more experienced co-workers. Under a Fordist system, by contrast, where both work schedules and shift rates are fixed, there is little room for manoeuvre and little chance for men to show off their ability or try to outdo the system or compete with others. Indeed, compliant companies are seen as spaces where there is neither the time nor the place to enact - and even produce - those valued masculine traits of competitive behaviour, showing off ability, and comparing strength and stamina. Men, therefore, consider employment in those export companies as tedious and its routines as only 
driven by the clock - 'you have to sit in your seat all day long!'. They find it hard to show commitment to an environment that seeks to separate work from social and masculine interaction. That's why they tell me that they 'just can't work there', and why they prefer to work in the - clearly male-dominated and male-run - flexible workshops.

But men also work hard to earn and spend. Much of the weekly wages goes to the family and covers core expenses such as house rent, food, clothes, health and increasingly saving and insurance policies. But if extra money is left, it is often spent on competitive consumption, which usually means a new mobile phone, a TV, a DVD player, or if the budget allows a motorbike. Mobile phones continue to be an artefact that attracts workers' interest and that inspires awe. They are great to impress coworkers with and are a constant topic of conversation on the shop-floor, as they are being passed around from table to table, their latest gadgets being compared and their functions and prices elaborately discussed. While the quality of the phone cameras was often debated in great technical detail, phones with internet access were the latest attraction, even though none of the tailors seem to have ever accessed the internet before or have any idea of how it could be of use to them.

It would be wrong, though, to depict young men's interest in hard work and good earnings as merely guided by a wish to engage in conspicuous consumption. To some extent, their commitment is driven by the obvious self-exploitation that piece-rates engender in workers everywhere. But there is more to hard work than just the material gain it yields. Perhaps what drives men in Tiruppur most is a strong desire one day to be able to set up a company of their own and move from tholilali (worker) to mudalali (owner). Even though most workers know that today this aspiration is increasingly hard to materialise, it does not distract them from seeking to move up the ladder wherever they can. While, as I have indicated above, women's working trajectories often tend to spiral downwards after marriage - when they quit garment work altogether or end up in more flexible, part-time and less well paid jobs -, male workers are constantly under pressure to move on and up. Much of this pressure comes from the family but some of it also emerges from the workplace itself where men work alongside other men and where ability, experience, knowledge, speed and 
stamina are constantly compared and commented upon, and where poor performance is immediately met with joking and teasing remarks.

So what 'career' can a male garment worker hope for in the Tiruppur industry? The strongest aspiration among male tailors, cutting masters and ironing masters is to become a contractor. While setting up one's own company is a more elusive dream, becoming a contractor is an attainable goal. For example, once a tailor has a few years of experience and a good grasp of different machines, designs and stitches, he may consider recruiting his own team and becoming a contractor. All he needs is to have some knowledge of the costings of a garment, an understanding of the wider production process and the ability to mobilise labour on flexible terms. While I cannot go into the detail here of how one becomes a contractor and why some men become successful contractors while others utterly fail, the point I want to make here is that becoming a labour contractor is seen as an attractive step up from being a skilled tailor or cutting master. It offers one the chance to earn more money through commissions, to recruit and manage a team of workers, and to be one's own boss (that is, fully in charge of an order). In fact, as middlemen and mediators between workers and company owners, contractors occupy a key node in the production process and yield a huge amount of authority on the shop floor. Although they are neither worker nor owner themselves, on the shop floor they nevertheless act as employer, supervisor and manager at the same time.

It is through employment in small workshops, where contract labour has become the dominant form of recruitment, that men see opportunities for upward mobility, even if the path is always risky and uncertain. Mohan, for example, has been a contractor on and off since 2005, but never quite managed to find his ground. While he did well as a contractor during the first half of 2009, by June he struggled again because of poorly rewarding orders and late payments from the company owner, leading him to give up as a contractor by the end of August and to start again as a tailor. The point I want to emphasise here is that in compliant companies, where labour contractors are by and large avoided, such opportunities to move up the production chain don't even exist. Tailors have few options for promotion in such companies, as supervisors and managers are often externally recruited and expected to have completed higher education. These differences in career prospects explain to a large extent why young, 
dynamic and ambitious men avoid getting stuck in dead-end jobs and instead explore whatever opportunities there are outside the larger, Fordist firm.

\section{Conclusion: What does a worker's critique of Fordism and CSR consist of?}

In this paper I have sought to make three points. Firstly, the co-existence of Fordist and flexible companies in Tiruppur challenges teleological understandings of capitalist modes of production which assume a linear transformation of Fordist into post-Fordist production regimes. The success of places like Tiruppur lies precisely in the articulation of multiple modes of production of which the Fordist and the Flexible regime are two extremes.

Secondly, supply companies like those in the Tiruppur garment industry are subject to seriously opposing pressures. On the one hand, there is a need to scale up and rationalise production in order to process bulk orders, adhere to tight lead-times and increase overall labour productivity. A Fordist assembly line and Taylorist principles of management are attractive means through which economies of scale can be materialised. Moreover, the move towards standardization and regulation of labour arrangements is also results from enhanced pressures from buyers, who as part of their CSR policies, ask their first-tier suppliers to comply with corporate codes and labour standards. There is a high degree of compatibility between Fordist/Taylorist modes of labour organisation and those promoted by corporate ethical standards of production. On the other hand, however, the vagaries of the global outsourcing networks also require supply firms to be responsive to constantly changing fashions, styles and markets, and thus to operate a highly flexible production regime. In Tiruppur, these pressures have led to the reproduction of multiple flexible firms and to the spread of labour contractors as a flexible mode of labour recruitment over time.

Thirdly, I have begun to explore what garment work means for those involved in it, and have described some of the non-monetary values and meanings that people attach to work. They include workers' appreciation of flexibility (or suitable temporal regimes), their attempts at retaining a degree of freedom and autonomy at work, their engagement with the workplace as a space for socialising and for the performance of gendered identities, and, finally, their involvement in work as a route to upward 
mobility. Those values and meanings affect how people can and do engage with garment work, and shape the choices they make, even though the choices of some are obviously more circumscribed than those of others. One of these choices, however, is to avoid compliant, Fordist firms and instead opt for employment in non-compliant, flexible workshops. By opting for the flexible factory and by verbally expressing their criticism of standardised and rationalised labour regimes, Tiruppur garment workers explicitly critique and actively seek to evade regimes and regulations that curtail their freedom and autonomy. This, I argue, amounts to a critique of the Fordist and Taylorist production regimes that have emerged within the industry and of the corporate ethical standards that seek to further consolidate them.

Global production networks and CSR interventions have significant transformative effects as they seek to generate particular regimes of production, particular values of work, and particular kinds of workers, or subjectivities. Let me conclude with a revealing comparison. In an evocative discussion of the transformation and privatization of a Polish food processing company (after having been taken over by an American company), Elizabeth Dunn (2004) describes the ways in which a specific category of person is imported in a Polish-based factory by American management. In the case of Poland, it was a neoliberal or post-Fordist concept of personhood that was brought to bear on Polish factory workers. A concept of a self-activating and self-motivating individual was promoted through new job evaluation and auditing mechanisms. Yet, this post-Fordist construct was contested by Polish workers who continued to draw on another concept of the working person, one which was rooted in a socialist idea of personal connections, nurtured by exchange and gift-giving (ibid.: 94-129). Dunn thus discusses how newly imported categories and routines are being reworked and contested by Polish workers, arguing that such contestations can form a basis for a critique of contemporary capitalism itself (2004: 8). In Tiruppur, by contrast, attempts to (re-)introduce Fordist-like regimes of garment work are similarly contested by the workers but here it is through active avoidance of regimes that stifle freedom and autonomy, and through workers' own manufacturing of flexible labour arrangements that enable them to reclaim dignity, independence and identity at work. In this, I believe, lies a criticism of not just of capitalism per se, but of capitalism's relentless search to subjugate and control labour at will. The high rates of labour turnover and the uncontrollable levels of daily absenteeism in Tiruppur's largest 
export companies testify to the limits of capitalism's ability to impose its own logic onto that of the workers whom it engulfs.

\section{References}

Barrientos, S., Dolan, C., \& Tallontire, A. (2003). A Gendered Value Chain Approach to Codes of Conduct in African Horticulture. World Development, 31(9), 1511-1526.

Barrientos, S. \& Smith, S. (2007). Do workers benefit from Ethical Trade? Assessing codes of labour practice in global production systems. Third World Quarterly, 28(4), 713-29.

Blowfield, M. and Dolan, C. (2008). Stewards of Virtue? The Ethical Dilemma of CSR in African Agriculture. Development and Change 39(1): 1-23.

Carrier, J. (1992). Emerging Alienation in Production: A Maussian History. MAN 27(3): 539-58.

De Neve, G. (2003). Expectations and Rewards of Modernity: Commitment and mobility among rural migrants in Tiruppur, Tamil Nadu. Contributions to Indian Sociology, 37 (1\&2), 251-280.

De Neve, G. (2009). Power, Inequality and Corporate Social Responsibility: The Politics of ethical Compliance in the South Indian Garment Industry. Economic and Political Weekly, Vol XLIV, No 22, May 30: 63-71.

Dolan, C. (2007). Market Affections: Moral Encounters with Kenyan Fairtrade Flowers. Ethnos 72(2): 239-61.

Dolan, C. (2008). Arbitrating risk through moral values: The case of Kenya Fairtrade. In De Neve, G., et al (eds), Hidden Hands in the Market: Ethnographies of Fair Trade, Ethical Consumption and Corporate Social Responsibility. Research in Economic Anthropology 27.

Dunn, E. (2004). Privatizing Poland: Baby Food, Big Business and the remaking of Labor. New York: Cornell University Press.

Dunn, E. (2005). Standards and Person-Making in East Central Europe. In A. Ong and S. Collier (eds), Global Assemblages: technology, politics and ethics as anthropological problems. Oxford: Blackwell Publishing.

Freeman, C. (2002). Designing Women: Corporate Discipline and Barbados's offshore Pink-collar Sector. In J. X. Inda and R. Rosaldo (eds), The Anthropology of Globalization: a reader. Oxford: Blackwell Publishing.

Harvey, D. (1989). The Condition of Postmodernity: An Inquiry into the Conditions of Cultural change. Oxford: Blackwell. 
Lund-Thomsen, P. and Nadvi, K. (2009). Global Value Chains, Local Clusters and Corporate Social Responsibility: A Comparative Assessment of the Sports Goods Clusters in Sialkot, Pakistan and Jalandhar, India. Technical Paper 17, PSD Technical Paper Series, UNIDO, Vienna.

Ong, A. (1987). Spirits of resistance and capitalist discipline: Factory women in Malaysia. New York: State University of New York Press.

Prieto-Carrón, M., Lund-Thomsen, P., Chan, A., Muro, A., and Bhushan, C. (2006). Critical perspectives on CSR and development: what we know, what we don't know, and what we need to know. International Affairs 82(5): 977-987.

Nadvi, K. (2004). The effect of global standards on local producers: a Pakistani case study. In: H. Schmitz (Ed.), Local Enterprises in the Global Economy: Issues in governance and upgrading (pp.297-325). Cheltenham: Edward Elgar.

Nadvi, K. (2008). Global standards, global governance and the organization of global value chains. Journal of Economic Geography, 8: 323-343.

Nadvi, K. \& Wältring, F. (2004). Making sense of global standards. In: H. Schmitz (Ed.), Local Enterprises in the Global Economy: Issues in governance and upgrading (pp.53-95). Cheltenham: Edward Elgar.

Salzinger, L. (2003). Genders in Production: Making Workers in Mexico's Global Factories. Berkeley: University of California Press.

Tallontire, Anne. (2007). CSR and Regulation: towards a framework for understanding private standards initiatives in the agri-food chain. Third World Quarterly 28(4): 775-791. 